\title{
寺廟，神壇の組織形態と都市コミュニティ：台北市東門地区を事例として THE ORGANIZATION OF TEMPLES AND SHRINES (JIBYOU, SINDAM) AND THE URBAN COMMUNITY IN EAST GATE AREA, TAIPEI CITY
}

\author{
關 銘 崇*, 布野修司** \\ Ming-chung CHUEH and Shuji FUNO
}

\begin{abstract}
The objective of this paper is to consider the community organization and the function of the religious facilities called Jibyou and Sindam in the East-gate area of Taipei city, Taiwan, which was formerlly the Japanese quater in the period of Japanese occupancy. It is generally pointed out that the Jibyous and Sindams in the rural area still function as one of the community facilities, but those in urban area are losing the close relation with local community. But this paper clarifies the fact that some of the Jibyous and Sindams are still playing a role as a community facility in urban area. This paper classifies the facilities in East-gate area that has no Jibyou before World War II into 4 types, some of which function as a traditional Jibyou.
\end{abstract}

Keywords: Temple (Jibyou), Shrine (Sindam), urbanization, block plannig, community organization, religeous service area 寺廟、神壇、都市化、街区構成、コミュニティ組織、祭祀圏

\section{1 研究の目的と背景}

\section{1-1 はじめに}

本稿は、台北の寺廟、神壇の組織形態に着目することによって、寺 廟、神壇のもつコミュニティ機能について考察することを目的とし ている。台湾の農村部において、寺廟が今日でも地域コミュニティ の重要な核としての役割を持っていることは、別稿*1によって明ら かにした。また、台北市における寺廟、神壇の建築類型とその分布 についても前稿*2において考察した。台北市において急速に都市化 が進展するなかで寺廟、神壇が增え続けていることは極めて興味深 い現象である。一方、都市部の寺廟、神壇については、地域コミュ ニティの核としての機能は衰退しつつあることが指摘される。しか し、寺廟、神壇の実態の把握は非常に乏しく、特に、寺廟、神壇と コミュニティとの関係に関する研究は皆無である。本稿は、寺廟、神 壇を都市施設のひとつとして位置づけながら、台湾の都市計画の盲 点となっている寺廟、神壇の実態把握を行い、地域施設計画のあり 方に新たな視点を提供することを大きな目的としている。

台湾の「宗教管理条例」*3 は、寺廟、神壇を同一の宗教施設とし て扱うが、その区別は公的登録の有無によっている。つまり登録の あるものを寺廟、そのたのものを一律、神壇と定する。未だ㛜密な 定義がない。一般的には、ある特定の人たちが共同出資して設立し たものが寺廟、個人が営利目的で設立したものが神壇と理解されて
いる。あるいは神媒（シャーマン）が常住して、信者に「法事」を 行い、その代わりに謝金を鿓うことが主目的のものが神壇とされる *4。こうした区別によると、同じ施設でも寺廟になったり、神壇に なったりすることがある。つまり共同出資者によって建てられた寺 廟の組織が崩壊し、個人の神壇に変わるケースも、個人の神壇が寺 廟組織に変わる場合も存在するのである。また、神壇が多くの信者 を集め、「委員会」を作り、都会を離れて山地で大きな寺廟を営む場 合もある*5。一方、施設を持たない宗教組織もある。「敬神会」や 「神明会」などといった名の組織を作り、順番に神像を移し、神像の ある信者の住居に集まって行事を行う。多くの場合、「敬神会」の組 織が寺廟の前身となる。本稿では、主に信者の分布地域と寺廟、神 壇との関係を視点に、施設のコミュニティ機能に着目して、寺廟、神 壇の類型化を試みる。また、地区で行われる祭祀に注目して寺廟、神 壇とコミュニティとの関係を考察する。具体的には、台北市の東門 地区を対象として取り上げる。

\section{1-2. 既往の研究}

台湾の寺廟については、農村部に関して人類学者を中心として多 くの研究成果がある*6。急激に增えつつある神壇については、近年、 数本の修士論文が、神壇の、特に施設の中心である神媒の社会的役 割に焦点を当てている*7。そのほとんどは、神媒による医療行為に ついての実状の把握とその評価を主とし、神壇のコミュニティ機能
* 京都大学大学院建築学専攻 大学院生.工修

** 京都大学工学研究科 助教授.工博
Graduate Student, Dept. of Architecture and Environmental Design, Faculty of Engineering, Institute of Kyoto Univ., M. Eng.

Assoc. Prof., Dept. of Architecture and Environmental Design, Faculty of Engineering, Institute of Kyoto Univ., Dr. Eng. 
について論ずるものはない。特に、本稿が対象とする急激に都市化 が進行する地域における神壇の形成過程に関する研究はほとんどな い。宋光宇の「神壇的形成---高雄市神壇調查資料的初歩分析」*8 は、高雄市について、新しく成立された神壇を対象にその形成原因 を論じ、多くの移民が出身地の澎湖島から分香 *9 ${ }^{9}$ して神壇を作っ ていることを指摘し、出身地別の移民団結が現代社会でも生きてい ることを主張している。条の研究は広域施設を対象としたアンケー 卜調査をもとに、神壇の概略的な成立過程を明らかにしているが、 施設の組織形態やコミュニティ機能についての議論は行っていな い。宋は単純に登録の有無による分類に従って、未登録のものを一 律神壇と定義しているが、本稿では寺廟、神㐭の具体的組織形態を 個々に問題としている。

\section{1-3 調㿽站域の迩定}

本稿が調査対象とする地区は、旧台北城の城外東にある旧日本人 居住地域である（図 1、2）。調查地域のほぼ中央に「東門市場」が ある。南北は仁愛路と愛国東路の間、東西は新生南路と杭州南路の 間を対象地区とする。中央には、幹線道路の信義路と金山南路がそ れぞれ東西、南北を走っている。東門地区の周辺には大規模な公共 施設が多い。西には中正記念堂、東には大陸系の住民による不法占 有地域を除去してつくられた「大安公園」がある。また、南には各 種学校が点在している。幹線道路の両側には商店が建ち並ぶが、路 地へ入ると、都心にも関わらず、閔静な住宅地が広がっている。

東門地区を調查地域として選んだ主な理由は二つある。一つは、 戦前期には宗教施設が存在しなかったため、資料や情報の把握が比 較的容易であること、もう一つは、歷史的に多様なコミュニティが 存在してきたことである。東門地区は、戦前においては日本人と 「本省人」が共住していた地区であり、戦後になって、多くの「外 省人」が日本人と入れ替わりに居住し始めた地区である*10。さら に近年、全国各地からの移住者が增え、多様な居住者構成をしてい る。東門地区には戦前まで存在しなかった寺廟、神壇が 11（表 1） 存在している。寺廟、神壇のような施設が、多様なコミュニティが 形成されるなかでとどのように設置されていったかを明らかにする 上で、東門地区は極めて興味深い地区である。

\section{1-4 調疽の方法}

$1 / 1000$ の都市地形図（台北市政府、1987 年）をべースマップと し、地区内を踏査しながら、街区の構成、建築類型、用途などをま ず記録した。調査対象である寺廟、神壇などの宗教施設をプロット し、全ての施設についてヒアリング調查を行った。旧暦の 2 月 23 日 （新攵 5 月 8 日）は、女神「媽祖」の生誕を祝う行事が行われる。地 区内の最も重要なこの祭りについては、ビデオや野帳によって記録 した。また、旧都心地域の「萬華地区」、新都心地域の「仁愛地区」、
ベッドタウンの「士林地区」及び山麓村落の「広興里」の四地区に 関するこれまでの調査*11 データも考察に用いた。調査は 1999 年 5 月 8 日〜 6 月 10 日に行った。

\section{2 杲門地区の街区構成}

\section{2-1 他区の形成}

東門地区は旧台北城の城外東に位置し、かっては広大な水田の一 部であった。植民地（日拠）時代から日本人居住区として発展を遂 げ、現在でも全域にわたって日本家屋が点在している（図4）。台北 城の周辺には、数力所日本人居住区が建設されていた。台北城の西 門外の西門町は商業地域であるのに対して、東門地区は高級住宅地 であった。地区内の日本家屋は戸建てのものがほとんどであったが、 電信局の職員寮などの公的機関の施設もあった *12。

多くの日本家屋は、戦後、大陸から撤退してきた高官達の宿舎と して使われてきた。そのため、台北市の他の地区より大陸系の住民 が多い*13。戦後まもなく、「外省人」が日本人に代わって居住した ところが興味深い。70 年代の高度成長期に、台北市の他の地域と同 様、急速に人口が増加し、台湾の中南部からの移入者により高密度 の商住混合地区が形成された（図 5)。

\section{2-2 犍築類型と施設分布}

東門地区は、幹線道路が拡張された以外、道路網は戦前の骨格を ほとんどそのまま残している。日本家屋の分布状態は図 4 の通りで ある。まとまった家屋群は南端の一角以外、点在するが、地区全体 に日本家屋が建ち並んでいた街区構成は読みとれる。戦後の混乱期 及び高度成長期から改築や新築が行なわれ、現在の街区に至ってい る。日本家屋の敷地は、場合によっては数軒まとめて、年代ごとに 異なる建築類型に建て替えられている。60、70年代は4階建ての「公 寓」(階段室型集合住宅)、80 年代以降は 5 階建以上の公寓もしくは 「大廈」(高層マンション)に建替るのが一般的であったが*14、現在 地区内に圧倒的多いのは高、低層の公寓であり、幹線道路に囲まれ た路地に分布している。一方、大厦は幹線道路沿いに建てられてき たが、とくに近年街区の奥まで建設されはじめている。同じく幹線 道路沿いによく見られるのは「透天」「街屋」である。「街屋」は伝 統的な店屋（町屋）の連䍶型のもの、平屋、 2 階建て、3 階建てま であり、戦前のものが中心である。「透天」とは、伝統的な間口奥行 きの敷地に直階段で $4 、 5$ 層構成をとるものをいう。本来 1 階から 上階まで同一家族が所有するものをいうが、現在では集合住宅形式 のものもいう。概念としては街屋を含むが戦後 50 年代から 60 年代 にかけて建てられた新しい建築類型である。また、(低昔仔) バラッ ク建築も目立っている。その多くは、老朽化した日本家屋を取り壊 して、簡易なものに造り変えたものである。

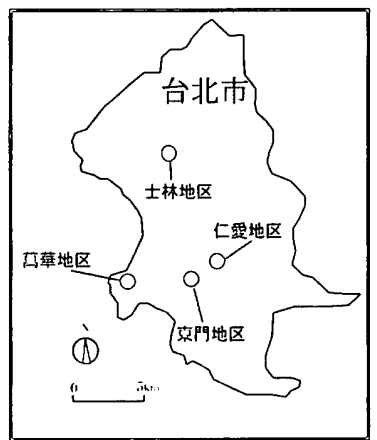

図 1 調䆞地区位置図

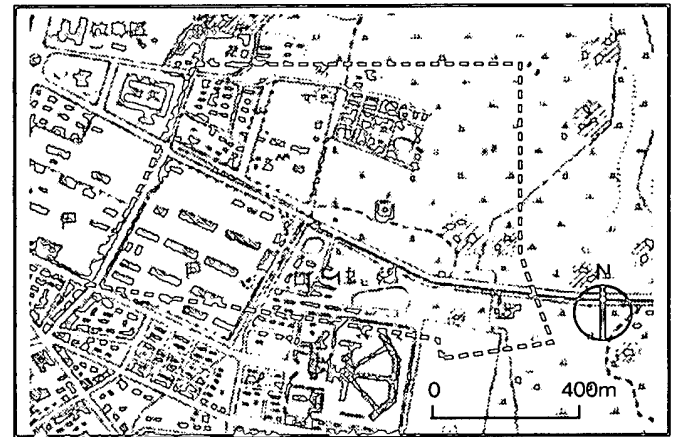

図2 植民地時代の真門地区(1927年) 出典：台湾堡図集、参考文献[15]

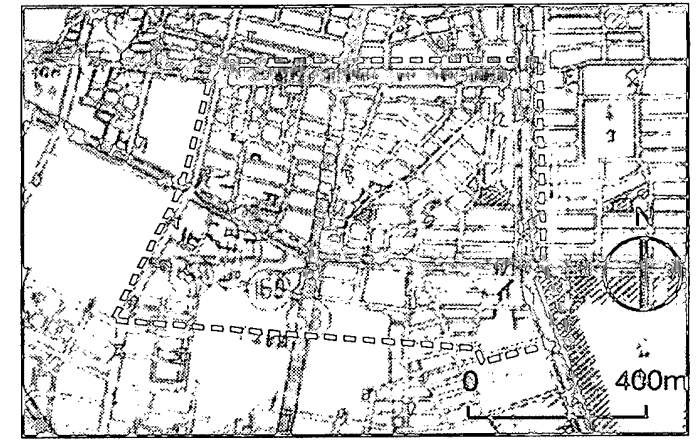

図 3 台北市都市計画図 1951 (台北市政府制作) 

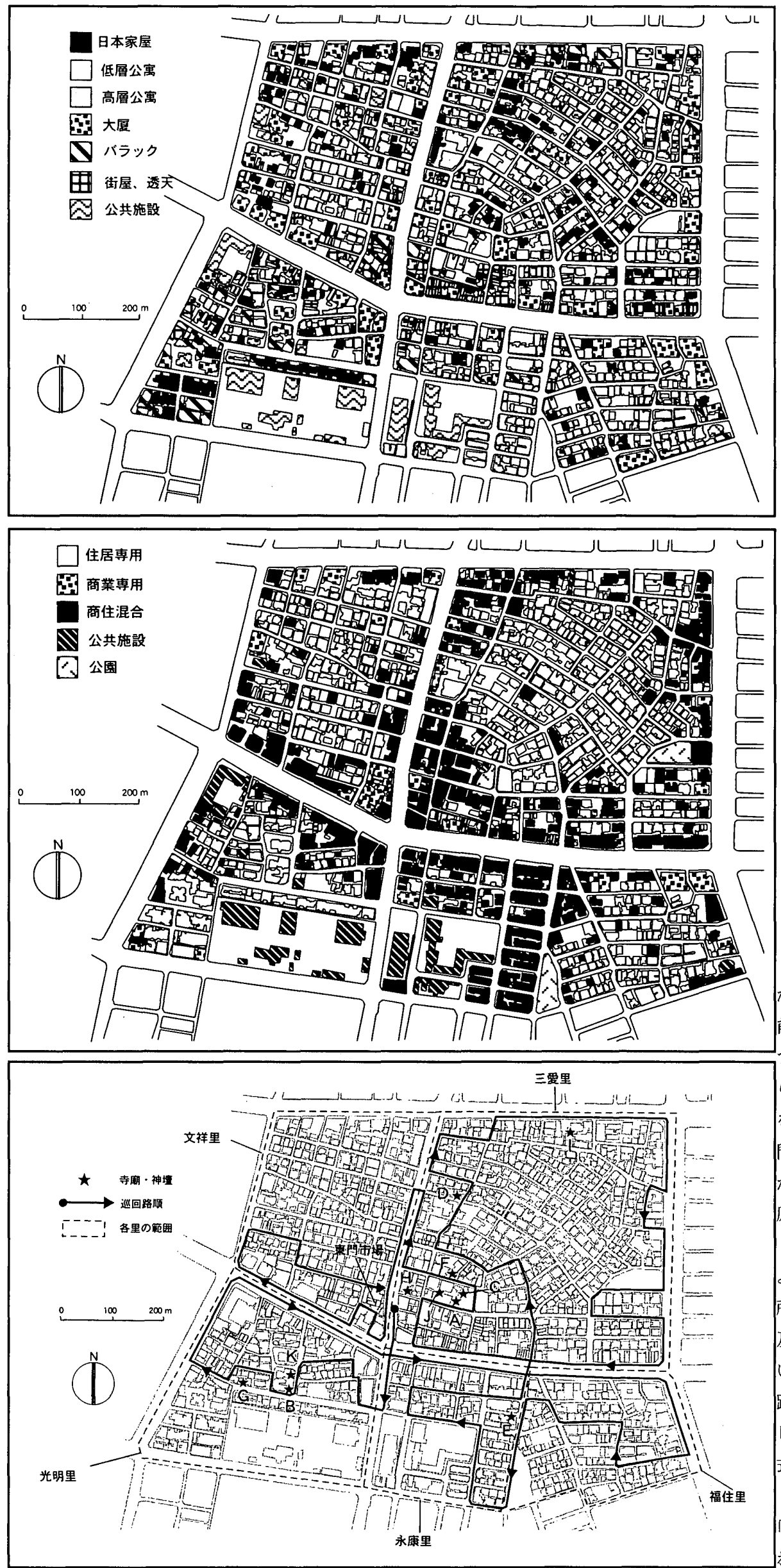

図4（上） 東門地区の建築類型

図 5 （中） 東門地区の施設分布

図6（下） 巡回路順之施設の分布図
幹線道路沿いを中心に商業もしくは店舗 併用住宅の「商住混合」施設が立ち並び、住 宅地を取り囲んでいる。また、大規模な公 共建築は地区の南に集中している。公園や

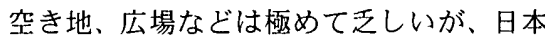
家屋が現存する敷地の庭には大きな榕樹が あり、高密度の居住環境に貴重な緑を残し ている。

急激な人口増加に道路整備が追いつか ず、交通問題は台北市の癌とも言われてい る。比較的新しく建てられた高層公寓や大 厦は一般に地下室に駐車場を設けるが、東 門地区内の大部分は設けておらず、幹線道 路から入る路地は車やバイクで埋められて いる。また、屋台が多く、活気のある過密 な屋外空間となっている。

\section{3 東門地区の寺廟、神壇}

東門地区の寺廟、神壇の組織概要を表 1 、 その立地を図 6 に示す。

\section{3-1 寺廟、神壇の形成とその概要}

東門地区には、現在多くの寺廟、神壇が あるが、前述したように、もともと旧日本 人地区であり、戦前には、寺廟、神壇は存 在しなかった。

しかし、本省人たちの間に民間信仰の組 織はすでに存在していたことがヒヤリング によって明らかになった。「敬神会」という 組織をつくり、それをコミュニティの核と して団結していたのである。施設がなくて も神像は信者の家に据えられ、様々な法事

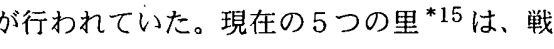
前には7つの股*16に分けられおり、年に一 つの股が祭りを主催していた。主催する股か らは炉主 $* 17$ が選ばれ、神像を供養する役割 を果たし、祭りを仕切った。植民地時代の東 門地区では日本人と本省人が混住していた が、後の東門地区の本省人のコミュニティの 原型はすでに存在していたのである。

施設「A」は 1946 年、福州人*18の神媒に 上って最初に建てられたが、神媒の死後、近 所の福州人が管理委員会を作り、現在は近隣 及び転出した福州人のための寺廟に変わって いる。本来は金山南路に立地していたが、道 路の拡張によって現在の公園の敷地内に移転 し、不法占拠の施設となっている。独立伝統 式の建築*19 である。

「B」は1930 年代に組織された本省人の 敬神会」がもとになって、1965 年に建てら れた。同じく道路の拡張によって、拡張され 
た道路沿いに移転した。近隣地区の信者の媳の場となっており最も 典型的な寺廟で、独立伝統式の建築である。

「C」は 1965 年に地区の人たちによって建てられた、公園内の不 法占拠の施設であるが、組織メンバーの転出により、現在は施設の 管理人（廟公）一人が管理維持している。個人経営で、一般的分類 では神壇に属すべきであるが、寺廟として認識されている。

「D」は 1990 年に現住所に移転してきた。本省人の神媒が、公寓 の4、5階を施設としている。地域住民と関係をもたず、地域の祭に も参加していない。典型的な不特定者を対象とする施設である。

「E」は、1987 年に外省人の教祖によって建てられた、全国 30 数 力所ある新興宗教の総㐭（総本山）である。8 階建ての大廈の $7 、 8$ 階を占め、一階の入り口に香炉と神像が固かれている。教祖の外省 人政治家との密接な関保で、外省人の信者が多く、政治的に無視で きない存在となっている。

「F」は、1975 年に客家人の神媒が建てた神㙗である。台湾では 少数派 ${ }^{*} 20$ の客家人は団結心が強く、また、独自の言語や伀統文化 を維持している。施設に集まるのはほとんど客家人で、信者の流動 性は少なく、一般的の神壇より、安定した信者層を持っている。

「G」は 1988 年に創始者が 5 階建の公寓を建て、その 1 階と地下 階を施設として使用している神壇である。特記すべきことは、この 施設は一切信者からの献金を受けず、全ての出費は主人の事業に よって賄っている、珍しい施設である。

「H」は1963 年に、本省人が「敬神会」を組織し、1987 年に現 住所に聖明宮を建てた。2 年後に、隣の公寓の 1 階を、事務室とし て借りている。1999 年の媽祖生誕祭りの主催者であった。

「I」は、1988 年に個人が建てた神壇である。簡易な建築でありな がら、唯一敨地内に広場を持ち、祭の際、道路を占拠せず行事をす べて敨地内で行える。個人創立の神壇にも関わらず、積極的に地域 参加し、3 年に一度祭りの主催を引き受けている。

「」」は、周氏一族が、150 数年前に大陸本土から持ってきた、代々 崇めている清水祖師の神像を、近隣の住民の説得で一般に公開する ため、1990年に建てた寺廟である。「K」は「B」の委員会の一人 が、1991 年につくった神壇である。直接「B」とは関係なく個人経 営である。大廈の 10 階に施設を設けている。

\section{3-2 騳祖生誕䉘りの運営}

東門地区の聖母生誕の祭りは年に一度、旧暦の 2 月 23 日に行われ る。現在では「B」「H」「I」の 3 施設が順番に、3 年に一度主催に 当たる。この行事は地区内の最も重要な、盛大な行事であり地区内 の寺廟、神㐭とコミュニティとの関係を知る上において、重要な手
かがりとなる。

媽祖生誕祭りは、主に、施設内で行う儀式と媽祖出巡（パレード） からなる。出巡は一日で終わるが、儀式は数日間続く。5 年前まで は「A」も主催していたが、委員会のメンバーたちの老齢化および 後継者不足のため、現在主催は行わない。「A」「B」「F」「J」「K」は 祭りは主催しないが、媽祖出巡には参加する。「D」「E」「G」は祭 りへ参加していない。1999 年の媽祖出巡の全長は約 2 キロにもな り、治路は信者と行列メンバーの礼洋活動で賑わった（写真(1)〜 (4))

主催に当たる寺廟、神壇は、東門地区の各里長を通して各隣の僢 長に依頼し、丁口銭 $* 21$ を徵収する。5つの里のうち「福住里」の 里長は外省人であり、主に本省人が参加しているこの祭りへの関心 が薄く、協力を拒否している。また、「光明里」の里長は「B」の委 員会との関係が悪く、丁口銭の徵収には非協力的であった。した がって、1999 年の丁口銭の徵収は実際には 3 つの里のみで 851 口 が徵収されただけである。なお、これら徽収された丁口銭は祭り全 体の運営に使われ（連絡、宣伝チラシの印刷、人形劇団の雇用など）、 出巡に参加していた各施設の資金は、各々の施設が負担した。

祭りは地区内の出巡が最も主要な行事で、一般の住民も積極的に 参加している。出巡の範囲や順路がこの地域の祭祀圈の範囲や参加 住民の分布に関係すると考えられる。

出巡の路順を各施設、商店の分布と照らしてみると、その決定に は二つの要素が考えられる。まず、出巡に参加している施設は必ず 順路内にある。また、順路は商業施設を中心に巡回している(図 4 、 6)。民間信仰は多神教であり、各々の神々には上下の神格がある。 各施設の前で各々の施設の神媒による儀式が行われる(写真(2))。出 巡の神々が商売繁盛をもたらす、そして店の悪霊を追い払うとされ ているのである。出巡は単に地区内を巡回するのではなく、所々の 「拝卓」(信者による巡回順路沿いに設けた供えものを載せたテーブ ル）を前にして出巡のメンバーによる除悪儀式が行われる（写真 (3)。除悪儀式によって信者から礼金が献上され、この礼金が各施設 の諸費用の大きな収入源となっている。

出巡の構成は三つの陣 (グループ)に分かれている。第 1 陣は、主 催者の「H」、第 2 陣は、「A」「F」「I」「J」、第 3 陣は、「B」「K」の それぞれのメンバーからなる。参加人数はおよそ 550 人、その大半 は施設関係者および信者であるが、巡回用の車両は専門業者に一任 されているため、その運転手を除けば、参加人員は 400 人強である。 「H」と「B」は地域密着型の施設であり、このような祭りのとき地 域の信者からの支援が比較的厚く、独自の陣を持つことができる。

表 1 施設俑码データー一覧

\begin{tabular}{|c|c|c|c|c|c|c|c|c|c|}
\hline 代号 & 寺㾰名 & 創立 & 創立動機 & 組織形態 & 立地形態 & 建築形態 & 媽相祭祀・施設維持費月 & 间施設の類型 & 主な信者対象 \\
\hline A & 天三堂 & 1947 & 福州出身シャーマン創立 & 初期は個人経営、現在は管理委員会制 & 公園内の不法占揕 & 独立伝統式 & 賽銭、信者奉納 & 特定集団型 & 福州出身者 \\
\hline B & 明宝宮 & 1965 & 地域住民敬神会を経て創立 & 委員会制 & 幹線道路沿い & 独立伝統式 & 賽銭、信者奉納 & 地域型 & 近橧住民 \\
\hline $\mathrm{C}$ & 福德宮 & 1969 & 付近住民の土地神崇遅 & 初期は管理委員会制、現在は個人管理 & 分公園内の不法占撄 & 独立伝統式 & 賽銭の小 & 地域型 & 近隣住民 \\
\hline D & 天霊殿 & 1973 & 個人のシャーマン創立 & 個人管理 & 住居の一部 & \multicolumn{2}{|c|}{ 公寓の5階と屋上改造信者奉納 } & 不特定対象型 & 不特定 \\
\hline E & 玄極総宮 & 1984 & 教祖創立 & 組織階級制 & 高層住居の一部 & 大厦の6,7階 & 信者奉納 & 組織拡大型 & 特定対象 \\
\hline$F$ & 忠義宮 & 1985 & 客家人シャーマン創立 & 固人管理 & 住居の一部 & 公寓の一階 & 信者奉納 & 特定集団型 & 客家人対象 \\
\hline G & 玉熄 & 1986 & 信者の病気を治すため & 個人管理 & 住居の一部 & 公寓の一階、地下室 & 所有者の事業による & 不特定対象型 & 不特定 \\
\hline $\mathrm{H}$ & 聖明宮 & 1987 & 地域住民敬神会を経て創立 & 管理委員会制 & 市場の一角 & 独立簡易型 & 賽銭、信者奉納 & 地域型 & 近隣住民 \\
\hline I & 慈仁宫 & 1988 & 個人シャーマン創立 & 個人管理 & 幹線道路沿い & 独立簡易型 & 信者奉納 & 不特定対象型 & 不特定 \\
\hline J & 祖師廟 & 1990 & 本来周姓一㵀の家謿、現在対外開 & 管理委員会制 & 駐車スペースを改造 & 独立伝統式 & 賽銭、周一㵀奉納 & 地域型 & 近慜住民 \\
\hline & 善化堂 & 1991 & 明宝宮ある委員個人創立 & 個人管理 & 高層住居の一部 & 大厦の10階 & 信者奉納 & 不特定対象型 & 不特定 \\
\hline
\end{tabular}



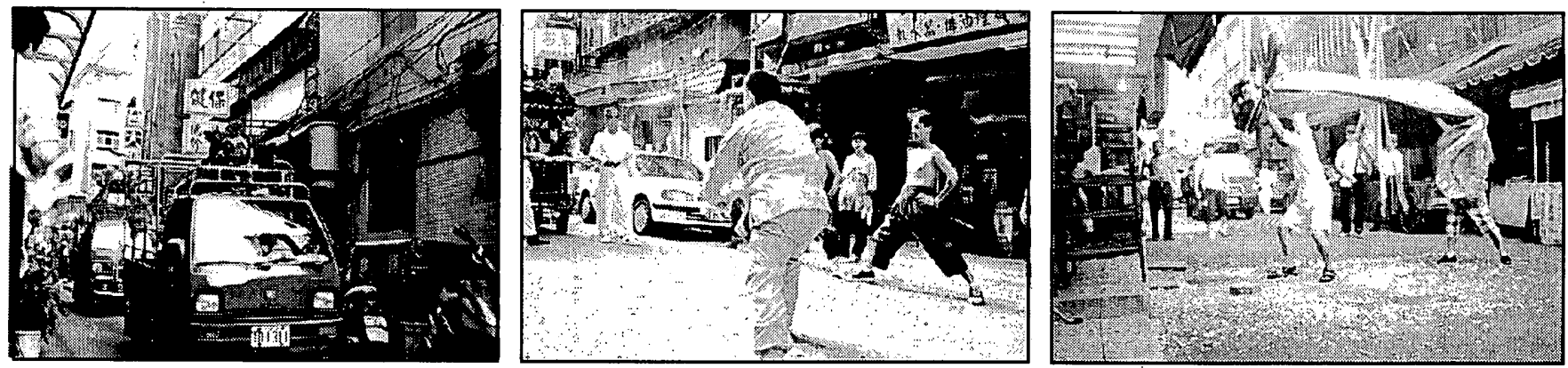

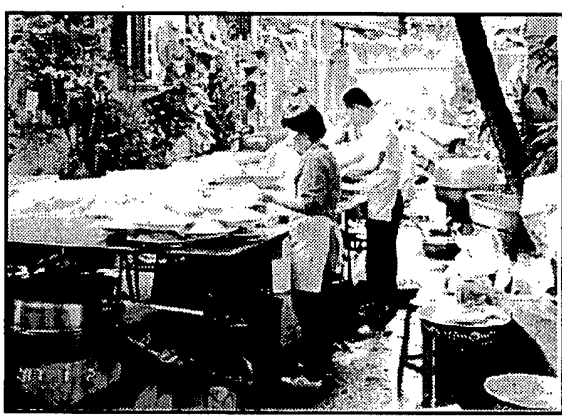

写真(1) (4)

(1) (上左) 㹟い路地に入 る車餘(2)（上中）神媒たち による議式(3)(上右) 舞による除要潾式(4)（下） 道路を占有して寔会の準储 をしている。

$\lceil\mathrm{K} 」$ の創始者は「B」との深い関係があるため、同じ陣になる。「A」 「F」「I」「J」は、いずれも規模が比較的小さいため、話し合いによっ て一つの陣を作ったと考えられる。

出巡が終ると、夕方から各々の寺廟、神壇による宴会が行われる。 参加メンバーはそれぞれが属す施設での宴会に参加する。宴会場は 「I」が私有の敷地内に設けている以外、すべて近所の道路を占有し て大がかりな仮設テント内で行われる（写真(4)）。

\section{4 寺廟、神壇の類型}

以上のように、東門地区の寺廟、神壇の信者の構成は様々である (表 1)。地区のコミュニティと関係を持つかどうか、特定の信者集 団を持つかどうかによって 4 つに分類できる。まず、特定の集団に よって利用維持されるか、不特定者が利用するかで大きく二つに分 れる。特定の集団を対象とする施設も、近隣地区内の集団を対象と するもの（地域型施設）と、地区を超えて広がる場合（特定集団型 施設）を区別することができる。また、不特定者が利用する施設も 全く近隣地区住民と関係をもたない新興宗教施設(組織拡大型施設) と近隣地区も利用するもの(不特定者対象型施設)が区別できる。各 寺廟、神壇のコミュニティ機能を各類型ごとに考察したい。

(1)特定集団型施設 特定の信者が継続的に施設を支えるが信者は 地区内に限定されない。つまり地区を越えた施設で、東門地区の 「A」「F」がこれにあたる。

宗教施設を核とする結社は、初期台湾の移民社会においては一般 的で、同一出身地の人達による、いわゆる地縁団結が行われてきた。 その後、商業社会を中心に各種業界の人たちによる業界結社が始ま り、地縁団結と並んで一般に見られる地域社会の形態となった。

東門地区の「A」は、戦後移民してきた福州人による集団で、本 来は典型的な地縁団結と言うべきだが、多くの先住集団のなかの少 数派の結社であり、業界結社の形態とよく似ている。「F」も同様で ある。個人の客家人が作った施設であるが、客家人の信者が集まり、 比較的安定したメンバーのコミュニティの場となっている。

特定の階層を対象とした施設であり、その構成員は明確に確認で
きるが、信者の分布は地区外に及んでいる。下に見る地域型施設と 同様、伝統の寺廟運営の手法により、集団の維持を計っている。

2不特定者対象型施設一般的に認識されているいわゆる「神壇」 をいう。信者の悩み事を神媒や霊能力者が癒してくれる施設である。 東門地区の「D」、「G」、「I」、「K」がこれにあたる。

不特定対象者型施設は、高度成長期から都市部のベッドタウンを 中心にその数を增やしてきた $* 22$ 。しかし、多くの施設経営者は非 協力的でこの類型の把握は最も困難である。その理由の一つは信者 のプライバシーの保護である。

100 以上の不特定対象者型施設を訪問したが、信者の住所を教え てくれた施設はわずか 3 力所である $* 23$ 。この 3 力所の信者の住所 を地図上にプロットしてみると、ある程度信者の分布形態が読みと れる（図 7、表 2)。施設の近所に住む信者もあるが、その分布は、 遙かに生活圈を越えていることが明らかである。また、信者の目的 は悩み事の解消がほとんどであり、一種の医療的行為の場であるこ とがこの分布からも理解できる。

地域との深い関わりが本来目的ではないため、経営者の意向によ り、その対応の違いは大きい。東門地区の「D」「G」「I「K」はす べて個人経営であるが、「D」は完全に地域との交流を拒否し、独立 した排地域的施設である。一方、他の施設は多かれ少なかれ、地域 との交流があり、少なくとも排地域的ではない。なかでも「I」のよ うに祭りの主催を担当するなど、積極的に地域活動に参加し、地域 型施設へ変貌しようとする施設もある。

(3地域型施設 いわゆる伝統的寺廟型の施設である。唯一祭祀圏 の確認が可能な施設である。「B」、「C」、「H」、「J」がこれにあたる。 都市部と農村部の地域型施設の運営手法や組織形態はよく似てい るが、最も大きな違いは祭祀圈内の信者の参加の密度である。「広興 里」では、村廟の祭りのとき外来のわずかの移住者を除き、ほぼ全 員が「丁口銭」を払っていた 24 。一方、東門地区は徵収対象となっ た三つの里、約 3 万人のうちわずか 851 口の丁口銭しか徵収できて いない。丁口銭のリストを調べてみると、約半数の 412 の出資者は 東門市場内とその周辺の商店である。東門地区全域に及ぶ祭りであ りながら、参加する住民は商業従事者を中心に、ある階層に限定さ れている。しかし、都市部でも、伝統的寺廟の運営手法で、コミュ ニティの形成、維持を計ろうとする施設は存在しているのである。

4組織拡大型施設 民間信仰の教義や儀式を新たに解釈し、とく に西洋の宗教システムを吸収し、新しい教義を持つ新興宗教団体の 施設をいう。信者は特定の人々によるが、特定集団型施設の信者の メンバーが安定しているのに対し、信者の拡大が著しく、それらの 施設は一力所に止まらず、広域にわたり複数の施設の連携にまで発 展するケースが多い。また、信者の教歴や能力によって神職が与え 


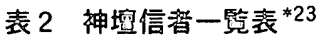

\begin{tabular}{|c|c|c|c|c|c|}
\hline \multicolumn{3}{|c|}{ 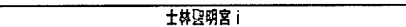 } & 住呞 & 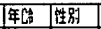 & 目的 \\
\hline \begin{tabular}{|r|} 
住丽 \\
\end{tabular} & 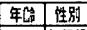 & 目的 & 自北市中唯路2段 & 28 女 & 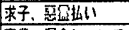 \\
\hline 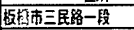 & $21 \mid$ gers & 呚经 & 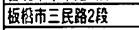 & 47 男 & 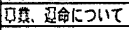 \\
\hline 進子得 & 19 男 & EReg & 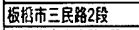 & 39 女 & 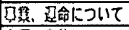 \\
\hline TSt? & 26 男 & 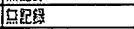 & 台北市金山南路2 2段 & 58 女 & 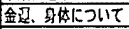 \\
\hline 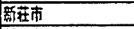 & 59 प्ger & GE2 & 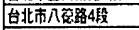 & 57 5 & 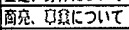 \\
\hline 惎䢂市 & 53 男 & geger & 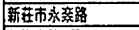 & 50男 & 年命を求加 \\
\hline ma: & 501 照跑 & 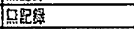 & 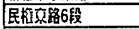 & 53㭷 & 每台乥求圾 \\
\hline 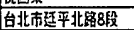 & 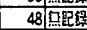 & 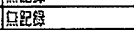 & 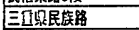 & 32 侽 & 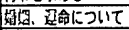 \\
\hline 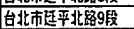 & 33 पूहE? & 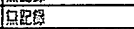 & 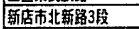 & 52 丽 & P佮LJU1T \\
\hline 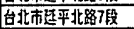 & 32 女 & 52 & 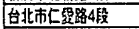 & 55 女 & 宅地下JUर \\
\hline 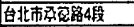 & 58 男 & 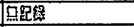 & 台北市西盟解 & 48 男 & 土地品を治める \\
\hline 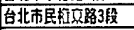 & 51 开 & 묠ㄹ & 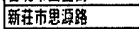 & 57 男 & 人嚗し \\
\hline 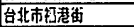 & $45 \sqrt{9}$ & 928 & 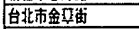 & 15 男 & 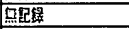 \\
\hline 台北市北投区 & 33 女 & 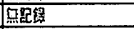 & 台北市酩國路2段 & $\begin{array}{l}52 \text { 女 } \\
\end{array}$ & و⿻𨈑㇒𠃋大 \\
\hline 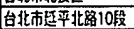 & 62 매묘 & Feper & 台北市北投区公僻路 & 34 女 & 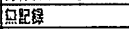 \\
\hline 台批市DII & 811 & Sieg & 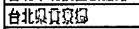 & 39 男 & 身体KD心 \\
\hline 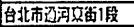 & 23 묘를 & treper & 自北市昆明留 & $\begin{array}{l}72 \text { 女 } \\
\end{array}$ & 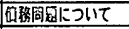 \\
\hline 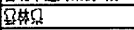 & 60) 男 & 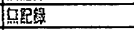 & 台北市口年路 & $4 \sqrt[3]{2}$ & 得命を求的る \\
\hline 此的平船盆 & 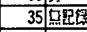 & 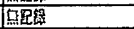 & 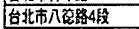 & 29 男 & 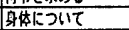 \\
\hline 台北市中山北路5段 & 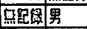 & ED㑢D & 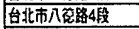 & 299男 & 身仗につ儿र \\
\hline 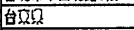 & 鸟足践男 & tQ法门 & 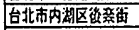 & 29 男 & 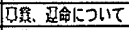 \\
\hline 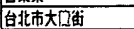 & 13 [5 & 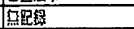 & 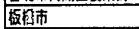 & 19 女 & 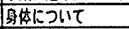 \\
\hline 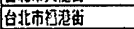 & 35 p & ER法口 & 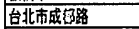 & 36 t女 & 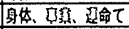 \\
\hline 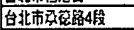 & 596 & 1028 & 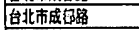 & 63 女 & 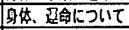 \\
\hline 合北市社中萑 & 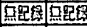 & 嘿䠰 & 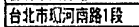 & 39 男 & 今年のD鸟 \\
\hline 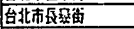 & 30 [1925 & DnEsLT & 台北市民和角路6段 & $2 女$ & 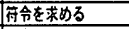 \\
\hline 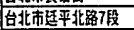 & 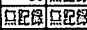 & 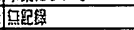 & 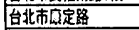 & 27 鼻 & D品下JIIT \\
\hline 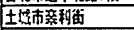 & 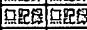 & CQ卩法了 & 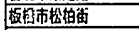 & 30 女 & 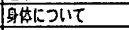 \\
\hline 査北市大剭 & $30 \mid 152$ & 묠ㄹ & 宣北市而定路 & \begin{tabular}{l|l|}
22 & $\hat{\mathrm{t}}$ \\
\end{tabular} & 求子 \\
\hline 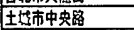 & Freg & EQ法】 & 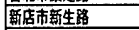 & 32) & 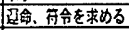 \\
\hline 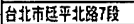 & 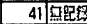 & 点跑 & 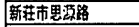 & 32 男 & 而命老冰める \\
\hline 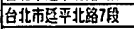 & 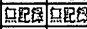 & 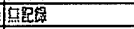 & 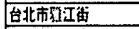 & $68 \sqrt{68}$ & SRINTIR \\
\hline 台北市吉林嗤 & 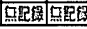 & 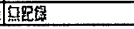 & 急北市抬江福 & 6 男 & 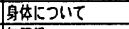 \\
\hline & & & 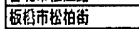 & 32 女 & 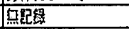 \\
\hline & 㻚究宫 ii & & 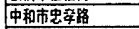 & 20 女 & 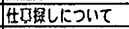 \\
\hline \begin{tabular}{|c|} 
住盾 \\
\end{tabular} & 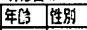 & 貝的 & 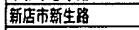 & 35 男 & 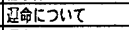 \\
\hline 中㲜市中安宙 ii & $29 / 8$ & 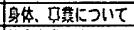 & 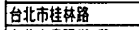 & 36 男 & 证命にכ11\% \\
\hline 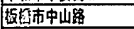 & 55 男 & 付命孛水める & 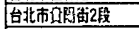 & 46 女 & 身体にJ \\
\hline 中和市中安汪 & $3 \dot{x}$ & 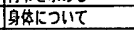 & 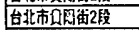 & 24 男 & tetitgisile \\
\hline EП口五谷北得 & 54 侽 & 符命老求める & 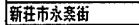 & 15 女 & T命につルT \\
\hline 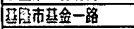 & 11 女 & 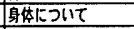 & 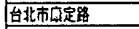 & $\begin{array}{ll}64 \text { 女 } \\
\text {. }\end{array}$ & 面充につに市 \\
\hline 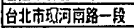 & 22 女 & 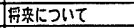 & 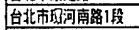 & 266 & 行合を求める \\
\hline 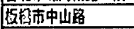 & 30 t女 & 每命赽求的る & 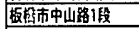 & $\begin{array}{l}54 \text { 女 } \\
\end{array}$ & 苻合を求める \\
\hline 三[累地河南照 & 401 & 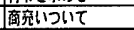 & 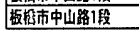 & 50 原 & 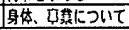 \\
\hline 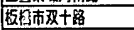 & 17]黑 & 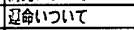 & & & \\
\hline 合北市安交到 & 63 女 & 身体につ儿र & & 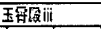 & \\
\hline 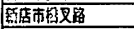 & $2 \sqrt{1}$ & 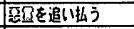 & 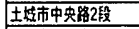 & 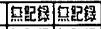 & Fege \\
\hline 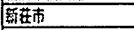 & 42 女 & 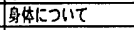 & 土枝继延和路 & 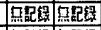 & 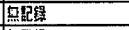 \\
\hline 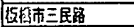 & 46 男 & 啇充いつ依 & 蒴店市新生路 & Erge & Gipg \\
\hline 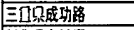 & 381 年 & 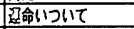 & 籍店市䇶生路 & 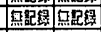 & 品战 \\
\hline 进化只大约 & 611 & fikl $2011 \tau$ & 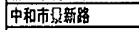 & 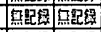 & 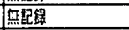 \\
\hline 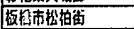 & $3 \dot{t}$ & 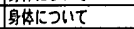 & 中和市只融路1段 & 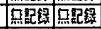 & Ecen \\
\hline 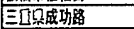 & 57]女 & 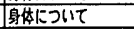 & 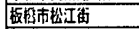 & 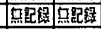 & 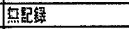 \\
\hline 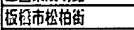 & $54 \hat{女}$ & 召金(1) & 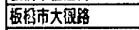 & 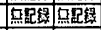 & ERge \\
\hline 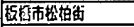 & 20 女 & 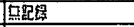 & 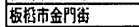 & 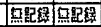 & GER \\
\hline 台北市安岢笛 & 63女 & 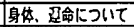 & 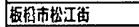 & 몰ㄹㄹㄹ & 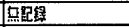 \\
\hline 辟北市西酉笛 & 27 男 & 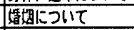 & 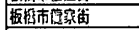 & G9: & finc \\
\hline 合北市平和酒路2 2段 & 16年男 & 身纳下 & 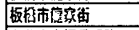 & 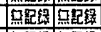 & t말 \\
\hline 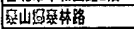 & 44 & 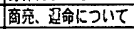 & 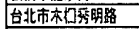 & 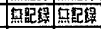 & 묨ㄷㄹ \\
\hline 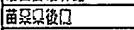 & 25) & Everef & 台北市本们和頁路 & 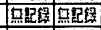 & 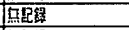 \\
\hline 台北市金山再蕗2段 & 62 男 & 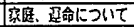 & 咸北市文山区貝山路路 & 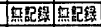 & 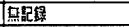 \\
\hline 台北市成功路4段 & 15. 原 & 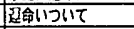 & E坛百大路 & 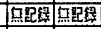 & 표료 \\
\hline 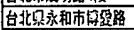 & 40 女 & 商充、筒命に须 & 固北市上要路 & 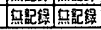 & Fon \\
\hline
\end{tabular}

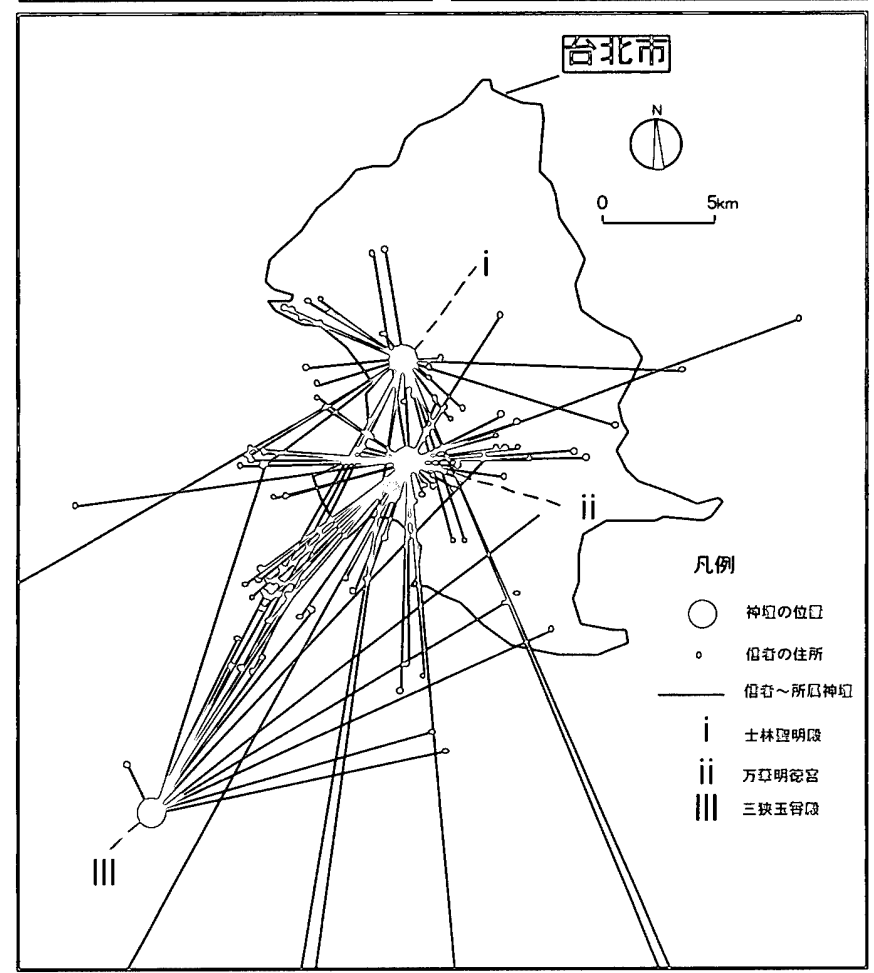

図 7 神壇信者分布図
られることがあり、低層幹部から教団の権力中枢まできめ細かく階 級が存在している。「E」がそれに当たる。

これまで調査を行った 125 力所の施設のうち、組織拡大型施設は 東門地区の「E」と士林地区の「中華道院」の 2 ケ所である。いず れも民間信仰の教義を元にするが、独自のシステムで運営を行う新 興宗教の施設である。信者間の連携は最も強く、信者の教歷と能力 によって神職へ昇進する階級組織による超地域的集団である。

「E」については、教祖は教義だけでなく、政治活動も行う。大陸 出身であるため、信者のメンバーも大陸出身者が多い。地域との関 わりはないが、外国の新興宗教との交流は積極的に行っている 25 。

\section{5 絔論}

本稿では、民間信仰施設である寺廟、神壇を 4 つに穎型化し、そ れぞれの組織やコミュニティ機能について考察した。今日の寺廟、 神壇は同じ民間信仰の伝統を受けついでいるが、その創立の動機や 組織形態、そしてコミュニティに対する機能は様々である。新たな 類型を提起することによって、明らかにできたのは以下のような点 である。

1 全台北市に関する包括的な解明は今後の作業になるが、東門地 区についての調査を基にすると、農村部と同様、現在でも都市部に おいて伝統的な形態を保持しながら生き続けている寺廟、神壇があ る。(3)の地域型施設がそうである。都市部の寺廟、神壇の祭祀圈消 隇論に対して再考すべき事例を本稿は提出している。

2 農村部の寺廟、神壇と都市部の地域型施設としての寺廟、神畦 (3はよく似ているが、コミュニティとの関係の密度は都市部の方が 薄い。東門地区における媽祖生誕祭りの組織構造と農村部の「広興 里」の構造とは酷似している*26。広興里の祭りの運営では 5 つの股 が順番に主催にあたる。東門地区の聖母の祭りは、 3 年に一度主催 が回ってくるかたちが採られている。しかし、農村部では地域住民 全体が参加するのに対して、都市部では地区内の一部を組織するに すぎない。

3 類型(4)以外の各類型は相互に転化しうる。(3)は、伝統的寺廟の 特性をもっており、地域住民のコミュニティの核として機能してい るが、(1)の場合、構成員はより限定され、特定の人たちのコミュニ ティ施設となっている。しかし、地域との関係は薄くなり、その信 者の分布範囲は(3ぼ明確でなく、より広くなる。転出等による地 域社会の変化によって(3)が同の類型になったことが考えられる(東 門地区の「A」がそれに当たる)。(2)は、いわゆる神壇で、そもそも 信者間の関係は薄いが、地域との関わりは主催者の意向によって異 なり、地域と密接に関連をもつものも存在する。(2)が(영に転化して いく事例は一般的であることは広興里の調查からも見られる。逆に (3が規模を縮小して個人的経営となる場合もある。神媒によって買 収され、神壇となる例（表2「iii」）が実際ある。また、東門地区の 「C」のように(3)が(1)の形態を経てさらに縮小される場合がある。

4 (4)は、いわゆる新興宗教の教団として理解される。地域の祭 りや活動、地域住民との交流にほとんど関心を持たない。信者間の 関係は強く、組織も強固である。(1)もまた(1)(2)(3)の各類型のいずれ かから発展したことが考えられるが、新興宗教として基本的に組織 原理を異にする面もある。東門地区の事例は政治結社化しており、 国際的な視野において、組織拡大を目指している。 
前稿*27 で明らかにしたように台北市において民間信仰施設とし ての寺廟、神壇は增え続けている。しかし、都市施設としての民間 信仰施設のもつ意義は現在ほとんど評価されていない。一方、特に 都市部における地域施設の設置は充分ではない。寺廟、神壇が、大 掛かりな祭りの時はもちろん、日常的に行われている行事やコミュ ニティの場として、現在でも機能していることは極めて重要である。 今後の地域施設論に新たな視野を提供することに、本稿のひとつの 意義があると考える。寺廟、神壇といった前近代の移民社会がコ ミュニティの核として使ってきた施設のもつ根深い生命力は、現代 の地域施設論の重要課題として決して無視できないと考える。

\section{謝辞}

本調查研究は、聖明宮[H]の前委員長陳照雄氏の協力に感謝する。多くの資料および地区 内のあらゆる情報の提供をしていただき、本稿の完成に決定的な授助をしていただいた。ま た、各施設の貫任者の協力および高松健一郎氏による調查協力に、あわせて感謝したい。

\section{註}

*1 そもそも「寺」とは仏教の施設、「嘲」とは道教の施設をいう。しかし、台湾における 寺と廟は、単に共同祭祀を行う宗教施設にとどまらず、コミュニティ施設として重要な役割 を果たしてきた。台湾の寺潮は移民たちの自己防衛のため、また移民間の䦚争が展開される なかで、同じ方言を用いる同一地方出身者の人たちが団結する、いわ妕る「地縁団結」のた めに中心的役割を果たしてきた。それが、中国における仏僧や道士の修行の場としての施設 と最も異なる点である。参考文献[1]参照。

*2 参考文献 [9]参照

*3 台湾の宗教施設に対する管理体制は民国 18 年（1929 年）に設定された「監督寺廟条 例」(中国本土で作られた法律) を沿用してきた。寺朝の登録の条件の一つは、独立建筑で あり、さらに宗教的「形態」をしていることである。この「監督寺湖条例」は明らかに、台 湾の都市化現象に対応しきれないものとして批判を浴びている。

*4「神壇」の語源を探れば、本来は宗教施設にある神像やその他の法器を載せる台、およ び道士が作法をする場を指す。明代中期、仏、道、檽の三教を融合して現在の民間信仰の形 態が成立する「堂」を経て、後に神媒（シャーマン）を主体に作法を行う施設全体のこと を指すようになる。参考文献[14] 参照

*5 参考文献[1] 参照。

*6 林美容は、草屯地区を考察し、村庪を基本単位として村廟間の組織權造を解明してい る。参考文献 $[2]$ 参照。

*7 丁念慈は、台北市にある神睟「永明宮」を事例として、神媒による「法事」のもつ社 会的意義を論じている。参考文献[3]参照。文栄光、王志明、末和、張旬らは、対象を異に しているが、共通しているのは、神媒の法事を一種の医療行為として捉えることである。医 旋人類学的解明や理論に大きな関心がある。参考文献 $[4] \sim[7]$ 参照。

*8 参考文献[8]参照

*9「分香」とは、ある本家の寺廟にある線香の灰の一部をもらい、新しい神像に需力を牲 き、分身を作る俄式である。台湾初期の移民社会では故鄉の寺朝から分香によって、新しい 神像をもって移民先で新しい寺廟を造ることが盛んに行なわれた。

*10「本省人」とは、高砂族の原住民を除き、戦前まですでに台湾に居住していた人達を 指す。その大部分は福建省之広束省からの移民である。一方、「外省人」とは戦後、国民党 と共産党による内戦後、大陸から撒退してきた人達を指す。戦後まもなく、王政に反発する 本省人の反乱を徹底的に綮压する事件、いかゆる「228事件」をきっかけに、本省人と外省 人の対立が目立つ、いまでも台清の人種問の問題として残っている。

*11 参考文献[1]、[9] 参照。

*12（図2）点線内、左下の部分は電信局の教地である。同じ敷地（図4）に現在は大がか りな建筑群が新築され、引き続き電信局として機能している。一部の睵員寮は戦前の宿舎を 使っている。

*13 1949年の大陸撤退によって200万人と言われる軍隊、難民が移住する。その多くは， 主に台湾の諸都市に居住し始めた。特に首都の台北市の外省人の人口が、1949年の散退を 境に、 9130 人から 16 万 6858 人と急激に臌れ上がった。参考文献[10]参照。また、当時の 空き地や公園が不法占败され、東門地区の周縁にある大がかりの不法占擢地、後にクリアラ ンスされ「大安公園」となったのもその一つである。東門地区を含め、旧台北城の東、南、 西を囲む半円形の地区は「外省人」の集中居住地域とされている。参考文献 [11] 参照。 *14 台北市によく見られるその他の住居類型は「国民住宅」である。「国民住宅」とは、一 般的に公共住宅のことで、初期のものは $4 、 5$ 階建てが主であったが、沂年、次第に高層化 しつつある。高首の「国民住宅」は「シンガポールスタイル」と呼ばれる。参考文献 [9] *15 台北市の行政単位として、区の下には「里」ささらにその下には「膦」がおかれてい る。台北市の総里数は 435 里（1995 年）である。高密度の都心や過体な山地を除き、1里
は平均約 2000 戸、約 1 万人からなっている。

*16「股」とは、グループのこと。とくに祭祀行事の時に使われる単位である。

*17「妒主」とは、施設もしくは組織の中心的存在である神像もしくはその分身を、一年 間自宅に迎える権利のある人のことである。神像を迎えられることは名誉なことであり、次 年度の祭りの主催への連絡人としての質任もある。妒主の決定はまず志願者の信者が神像の 前で、木片を地下に落とし、その木片の裏表の凶吉をもって決められる。つまり神が炕主を 選んでいると信じられている。

*18 台湾の福州人は客家人と同様、団結心が強いとされている。台湾の大部分の移民の出 身地は福建省南部である。いま台湾の公式用語は北京語であるが、大部分の人は台湾語も話 せる。この台湓語が福建省南部の方言である。一方、福建省の北部にある福州は異なる方言 で、台湾語と福州語はお互いに通じない。

*19 別稿の研究では、台北市の寺廟、神壇を街屋付属型、透天付属型、公寓付属型、国 民住宅付属型、大圈付属型、バラック付属型、民家付属型、伝統独立型、街屋独立型、ハ ラック独立型、農家独立型として類型化している。参考文献[1]参照

*20「台湾地誌」によれば、客家系の人口は約 15 パーセントである。参考文献[10] 参照 *21「丁口銭」とは、祭祀のときの一人当りの出資額のことである。

*22 参考文献[9] 参照

*23 信者のプライバシーを守るため、信者の住所は「路」以下の詳しいもの、そして氏名 を記入しない条件として今回のテーターを取ることが承認された。そのなか、「ii」のデー ターが最も完全で、住所をはじめ年鮯、性別、目的などが記録されているが、住所以外、「门1 がその大半、「iii」は無記録であった。但し、筆者のヒアリングによれば、「iii」の信者の目 的は「ii」に近い広笔围に渡っているが、「 j」は亡霊法事に偏っている。データーはそれ ぞれ「i」は1999年 4 月 2 日〜 4 月16日、「ii」は1997年3月16日〜19日、「iii」は 1998 年 10 月 1 日〜 11 月 2 日、施設を訪れた名簿の内容である。

*24 参考文献[1] 参照

*25「E」は、参考文献[13]の教義をまとめた書物を始め、月刊誌も発刊している。国際交 流はアジアに止まらず、中南米やアフリカにも積極的に活動を行っている。参考文献[13]。 *26 前稿 (参考文献[1]) では、典型と思われる台北の噥村部広興里について、その組織構 造と寺廟の祭祀圈について分析し、1 広興里の寺廟、神瓖は、「土着型」外来型」の二つ に分類できる。「土着型」寺潮は地域のコミュニティの核として、依然として重要な役割を 果たしている。一方、「外来型」寺廟および外来人口の参入は、本来明確であった祭祀圈の 構造を変えつつある。2「土着型」は地域住民が共同で出資して建てたものであり、以前の ように原住民による攻綮の心配はなくなったが、外来者を篦戒する意識は以前から根強く生 きている。一方、「外来型」のものは必ずしも地域住民と密接な場所に立地していない、な どを明らかにした。

*27 参考文献[9] 参照

\section{主要文献}

（1］闒銘崽、田中貞彦、布野修司、「新店市広興里の集落組織と寺廟の祭祀圈」『日本建築 学会計画系論文集第 521 号、pp.175-181、1999 年 7月

[2] 林美容、「由祭祀圈来看草屯的地方組織」『中央研究院民族研究所集刊第 62 期』 1986 年

[3] 丁念慈、『民間神壇「解事」服務的社会与文化意義-- 北投永明宮為例」清華大学修士 論文、1997 年

[4] 文栄光、「要神也要人--- 精神持病与民俗療法」『民間信仰与社会研討会論文果 pp.102-115月、東海大学、台湾省民政庁主瓣、1982 年

[5]王明志、『台北市基隆路的一個民俗医生和他的信徒』、台湾大学考古人類学系学士論文、 1971 年

[6] 末和、『台湾神媒的社会功能 --- 一個医療人類学的探討d、台湾大学考古人類学研究所 修士論文、1978 年

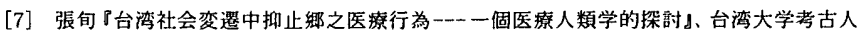
類学研究所修士論文、1981 年

[8] 未光宇、「神壇的形成---高雄市神㙵調查資料的初步分析」『寺謿与民間文化研討会論 文集』、漢学研究中心編集、文建会主㲔、1995 年

[9]䦥銘崇、田中貞彦、布野修司、「台北市の「寺廟」「神壇」の建築類型とその分布に関 する考察」『日本建築学会計画系論文集 第 526 号、185-192、1999 年 12 月』

[10] 陳正祥、『台湾地誌小、志文出版社、1987 年

[11] 台北市政府新聞処編印、『台北城の故事』、1993 年

［12］台北市政府民政局編印、『台北市寺廟登記工作手冊』、1994年 3 月

[13] 亥子道宗教法王厅 編印、P認識亥子道宗教』1997 年12月

[14] 品理政、『伝統信仰与現代社会小、稲郷出版社、1992 年

［15］大日本帝国陸地测是部、『台湾堡図集』、1927 年

(2000年 2 月 24 日原稿受理, 2000 年 6 月 20 日採用決定) 